\title{
ANALISIS PENGENDALIAN ALAT KESEHATAN NON ELEKTROMEDIK STERIL DAN NON STERIL MENGGUNAKAN METODE ABC DI SALAH SATU PENYALUR ALAT KESEHATAN KOTA BANDUNG
}

\section{Yusuf Supriadi, Nida Yulianti Muchtar dan Akhmad Priyadi}

Akademi Farmasi Bumi Siliwangi Bandung, Indonesia

Email: jusufspriadi@gmail.com, nidamuchtar303@gmail.com dan akhmadpriyadi@yahoo.com

\section{Abstract}

The purpose of this research is to know the management of inventory into groups $A$, $B$ and $C$ based on the analysis of Activity Based Costing (ABC) method of use value and investment value in one of the distributors of medical devices in Bandung. This type of research is non-experimental research that is descriptive quantitative. The data is collected by retrospectively, i.e. taking sales report data for one year, namely January 2018 - December 2018. Inventory control helps meet customer needs, affects customer satisfaction levels and also high-value investments require proper control to reduce costs incurred. From the analysis of the classification of $A B C$ usage value obtained that non-electromedic non sterile medical devices entered into group A 47 items (14.46\%) sales percentage $81 \%$ (31,501), Group B 89 items $(27.38 \%) 15 \%(5,892)$ and group $C 189$ items $(58.16 \%)$ sales percentage $4 \%$ (1,570), while sterile non-electromedic medical devices entered into group A 28 items (13.8\%) sales percentage $81 \%$ (44,331), Group B 46 items (22.7\%) sales percentage $15 \%$ (8,244), group C 129 items (63.5\%) sales percentage of $4 \%$ (2,252). And for abc classification the investment value was obtained that non electromedic non sterile medical devices entered into group A 77 items (23.7\%) cost percentage $81 \%$ (RP. 680,512,818), Group B 100 items (30.77\%) cost percentage $15 \%$ (Rp. 127,926,383), group C 148 items $(45.53 \%) 4 \%$ fee percentage (Rp. 34,299,125), while for non-electromedic sterile medical devices entered into group A 45 items (21.17\%) cost percentage 81\% (Rp. 309,177,082), Group B 56 items (27.59\%) cost percentage 15\% (Rp. 58,567,428), group C 102 items $(50.25 \%) 4 \%$ fee percentage (Rp. 15,740,728).

Keywords: $A B C$ analysis of investment value; $A B C$ analysis of disposable values; inventory control

\section{Abstrak}

Tujuan dari penelitian ini adalah mengetahui pengelolaan persediaan alat kesehatan yang dikelompokkan menjadi A, B dan $\mathrm{C}$ berdasarkan analisis metode Activity Based Costing (ABC) nilai pakai untuk memenuhi kebutuhan dan nilai investasinya pada salah satu distributor alat kesehatan kota Bandung. Jenis penelitian ini adalah penelitian non eksperimental yang bersifat deskriptif kuantitatif. Data dikumpulkan dengan cara retrospektif, yaitu mengambil data laporan penjualan selama satu tahun, yaitu Januari 2018-Desember 2018. Pengendalian persediaan membantu memenuhi 
kebutuhan alat kesehatan pelanggan, mempengaruhi tingkat kepuasan pelanggan dan juga investasi yang bernilai tinggi memerlukan pengendalian yang tepat untuk menekan permasalahan biaya yang mungkin terjadi. Dari hasil analisis klasifikasi ABC nilai pakai didapat bahwa alat kesehatan non elektromedik non steril masuk kedalam kelompok A 47 item (14,46\%) persentase penjualan 81\% (31.501), Kelompok B 89 item $(27,38 \%)$ persentase penjualan 15\% (5.892), dan kelompok C 189 item $(58,16 \%)$ persentase penjualan $4 \%$ (1.570), sedangkan alat kesehatan non elektromedik steril masuk kedalam kelompok A 28 item (13,8\%) persentase penjualan $81 \%$ (44.331), Kelompok B 46 item (22,7\%) persentase penjualan $15 \%$ (8.244), kelompok C 129 item (63.5\%) persentase penjualan 4\% (2.252). Dan untuk klasifikasi ABC nilai investasi didapat bahwa alat kesehatan non elektromedik non steril masuk kedalam kelompok A 77 item $(23,7 \%)$ persentase biaya $81 \%$ (RP. 680.512.818), Kelompok B 100 item (30,77\%) persentase biaya 15\% (Rp. 127.926.383), kelompok C 148 item (45,53\%) persentase biaya 4\% (Rp. 34.299.125), sedangkan untuk alat kesehatan non elektromedik steril masuk kedalam kelompok A 45 item (21,17\%) persentase biaya 81\% (Rp. 309.177.082), Kelompok B 56 item (27,59\%) persentase biaya 15\% (Rp. 58.567.428), kelompok C 102 item $(50,25 \%)$ prosentase biaya 4\% (Rp. 15.740.728).

Kata kunci: analisis $\mathrm{ABC}$ nilai investasi; analisis $\mathrm{ABC}$ nilai pakai; pengendalian persediaan

Coresponden Author

Email: jusufspriadi@gmail.com Artikel dengan akses terbuka dibawah lisensi

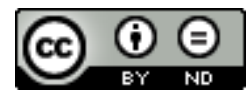

\section{Pendahuluan}

Pelayanan kesehatan alat kesehatan merupakan komponen yang penting disamping obat, hal ini menjadikan banyak ragam jenis, bentuk dan pabrik pembuatnya (Tampubolon, Saragih, Reza, Epicentrum, \& Asosiasi, 2013). Alat kesehatan dapat digolongkan berdasarkan: Alat kesehatan non elektromedik radiasi dan elektromedik radiasi; Alat kesehatan non elektromedik steril dan non steril; serta produk diagnostik invitro (Kemenkes, 2010).

Alat kesehatan yang beredar banyak ragam dan jenisnya, maka perlu Penyalur Alat Kesehatan (PAK) (Perizinan \& PAK, 2011) untuk mendistribusikan alat kesehatan ini. Syarat untuk menjadi PAK yaitu: memiliki izin yang diberikan oleh Direktur Jenderal; memiliki penanggung jawab teknis alat kesehatan yang bekerja penuh; memiliki sarana dan prasana yang memadai; memiliki bengkel atau bekerja sama dengan PAK dalam melaksanakan jaminan purna jual alat kesehatan; melaksanakan Cara Distribusi Alat Kesehatan yang Baik (CDAKB) (Kemenkes, 2010).

Pada observasi awal yang dilakukan oleh peneliti, terdapat beberapa kekosongan barang di salah satu PAK kota Bandung yang mengakibatkan konsumen beralih ke PAK lain dan terjadi pula beberapa penumpukan barang yang membuat barang tersebut 
beberapa menjadi rusak dan beberapa expired, maka diperlukan manajemen persediaan alat kesehatan yang bertujuan untuk menjamin ketersediaan dan terjangkaunya pelayanan kesehatan yang efektif dan efisien (Kemenkes, 2011).

Untuk membantu pengendalian persediaan secara efektif dan efisien dapat digunakan Metode Activity Based Costing (ABC) (Pujawati, 2015), sehingga memberikan informasi dalam rangka memprioritaskan dan membantu menentukan alat kesehatan mana yang harus dipesan (Reddy \& Elanchezhian, 2008). Sistem informasi berbasis aktivitas pada Metode $\mathrm{ABC}$ di rancang untuk memotivasi pengelola dalam melakukan pengurangan biaya jangka panjang melalui pengelolaan aktivitas (Mulyadi, 2016).

Metode $\mathrm{ABC}$ juga dapat digunakan penyalur alat kesehatan untuk meningkatkan kualitas dalam pelayanan, mengurangi aktivitas perusahaan yang tidak perlu dan efisiensi perusahaan (Suciati, Adisasmito, \& Wiku, 2006) dan (Farida, Sunandar, \& Hetika, 2017).

\section{Metode Penelitian}

Jenis penelitian ini adalah penelitian non eksperimental yang bersifat deskriptif kuantitatif (Creswell, 2016), data dikumpulkan dengan cara retrospektif, yaitu mengambil data dari populasi laporan penjualan di salah satu PAK kota Bandung selama satu tahun, yaitu Januari 2018 sampai dengan Desember 2018 (Sugiyono, 2011). Instrumen yang digunakan dalam pengambilan data adalah laporan penjualan alat kesehatan pada periode Januari-Desember 2018 yang terdapat pada sistem informasi dan daftar harga alat kesehatan.

Data yang telah didapatkan melalui rekapan laporan penjualan selama tahun 2018 kemudian diolah dengan aplikasi microsoft excel. Menggolongkannya kepada alat kesehatan non eletromedik steril dan non steril kemudian melakukan perhitungan (Pudjiantoro, 2008).

\section{A. Nilai Pakai}

1. Mengkasifikasikan laporan penjualan alat kesehatan menjadi golongan alat kesehatan non elektromedik steril dan non steril selama periode JanuariDesember 2018.

2. Menghitung rata-rata penjualan setiap item alat kesehatan non eletromedik steril dan non steril

3. Melakukan pengurutan data tabel berdasarkan rata-rata penjualan alat kesehatan non elektromedik steril dan non steril dari yang terbesar hingga terkecil.

4. Menentukan persen rata-rata penjualan setiap item dari jumlah penjualan total.

5. Menghitung persen kumulatif setiap item penjualan

6. Mengelompokkan berdasarkan persentase kumulatif. Penjualan yang mempunyai angka kumulatif 0\%-80\% diklasifikasikan ke dalam kelompok A, 80\%-95\% diklasifikasikan ke dalam kelompok B, dan 95-100\% diklasifikasikan ke dalam kelompok $\mathrm{C}$. 


\section{B. Nilai investasi}

1. Menghitung jumlah rata-rata penjualan tiap tahun untuk setiap item satuan barang.

2. Membuat daftar harga jual dari setiap item alat kesehatan.

3. Menghitung penjualan dikalikan dengan harga jual setiap alat kesehatan untuk mendapatkan nilai investasi.

4. Melakukan pengugurutan nilai investasi dari yang terbesar hingga terkecil, kemudian menetukan persen nilai investasi.

5. Melakukan perghitungan nilai investasi kumulatif.

6. Mengelompokkan barang persediaan yang didasarkan atas persen nilai kumulatif.

Apabila perhitungan nilai frekuensi kumulatif antara 0\%-80\% maka dikelompokkan sebagai kelompok A Apabila berkisar antara 80-95\% akan dikelompokkan sebagai kelompok B, dan nilai frekuensi antara 95-100\% akan dikelompokkan sebagai kelompok $\mathrm{C}$.

Subjek penelitian yang digunakan dalam penelitian ini adalah laporan penjualan alat kesehatan yang terdapat di salah satu Penyalur Alat Kesehatan Bandung bulan Januari sampai dengan Desember 2018.

Sample penelitian harus mengandung kriteria inklusi yaitu: Data laporan penjualan di salah satu penyalur alat kesehatan kota Bandung bulan Januari sampai dengan Desember 2018 yang termasuk golongan alat kesehatan non elektromedik steril dan non steril.

Sample pada penelitian ini diambil berdasarkan pehitungan menggunakan rumus Solvin dengan jumlah seluruh populasi $(\mathrm{N})$ adalah jumlah item alat kesehatan non elektromedik non steril dan steril di salah satu PAK kota Bandung yang masuk kriteria inklusi.

Rumus Slovin

$\mathrm{n}=\mathrm{N} /\left(1+\mathrm{Ne}^{\wedge} 2\right)$

Keterangan:

$\mathrm{n}=$ Jumlah sampel minimal

$\mathrm{N}=$ Jumlah seluruh Populasi

$\mathrm{e}=$ Margin Error

Perhitungan sample analisis $\mathrm{ABC}$ alat kesehatan non elektromedik non steril bedasarkan Rumus Slovin

$\mathrm{N}=1720$

$\mathrm{e}=0,05$

$\mathrm{n}=1720 /(1+1720 . \llbracket[0,05 \rrbracket \wedge 2)$

$\mathrm{n}=325$ item

Perhitungan sample analisis $\mathrm{ABC}$ alat kesehatan non elektromedik steril bedasarkan Rumus Slovin

$\mathrm{N}=410$

$\mathrm{e}=0,05$ 


$$
\begin{aligned}
& \mathrm{n}=410 /(1+410[0,05 \rrbracket \wedge 2) \\
& \mathrm{n}=203 \text { item }
\end{aligned}
$$

Dan untuk kriteria ekslusinya yaitu: Data laporan penjualan dan pembelian di salah satu penyalur alat kesehatan kota Bandung bulan Januari sampai dengan Desember 2018 yang tidak termasuk golongan alat kesehatan non elektromedik steril dan non steril.

Objek penelitian yang digunakan penulis adalah pengendalian alat kesehatan non eletromedik steril dan non steril menggunakan metode $\mathrm{ABC}$ di salah satu penyalur alat kesehatan kota Bandung bulan Januari 2018 sampai dengan Desember 2018.

\section{Hasil dan Pembahasan}

\section{A. Hasil Penelitian}

Tabel 1

Data Analisa ABC Nilai Pakai Alat Kesehatan Non Eletromedik Non Steril Di Salah Satu Distributor Alat Kesehatan Bandung

\begin{tabular}{cccccc}
\hline No & $\begin{array}{c}\text { Kelompok } \\
\text { Alat } \\
\text { Kesehatan }\end{array}$ & $\begin{array}{c}\text { Jumlah } \\
\text { Item }\end{array}$ & $\begin{array}{c}\text { Penjualan } \\
\text { (buah) }\end{array}$ & $\begin{array}{c}\text { Persentase } \\
\text { Item }(\%)\end{array}$ & $\begin{array}{c}\text { Persentase } \\
\text { Penjualan } \\
(\%)\end{array}$ \\
\hline 1 & A & 47 & 31.501 & 14,46 & 81 \\
2 & B & 89 & 5.892 & 27,38 & 15 \\
3 & C & 189 & 1.570 & 58,16 & 4 \\
\hline & TOTAL & 325 & 38.693 & 100 & 100 \\
\hline
\end{tabular}

Tabel 2

Data Analisa ABC Nilai Pakai Alat Kesehatan Non Eletromedik Steril Di Salah Satu Distributor Alat Kesehatan Bandung

\begin{tabular}{cccccc}
\hline NO & $\begin{array}{c}\text { Kelompok } \\
\text { Alat } \\
\text { Kesehatan }\end{array}$ & $\begin{array}{c}\text { Jumlah } \\
\text { Item }\end{array}$ & $\begin{array}{c}\text { Penjualan } \\
\text { (buah) }\end{array}$ & $\begin{array}{c}\text { Persentase } \\
\text { Item }(\%)\end{array}$ & $\begin{array}{c}\text { Persentase } \\
\text { Penjualan } \\
(\%)\end{array}$ \\
\hline 1 & A & 28 & 44.331 & 13,8 & 81 \\
2 & B & 46 & 8.244 & 22,7 & 15 \\
3 & C & 129 & 2.252 & 63,5 & 4 \\
\hline & TOTAL & 203 & 54.827 & 100 & 100 \\
\hline
\end{tabular}

Tabel 3

Data Analisa ABC Nilai Investasi Alat Kesehatan Non Eletromedik Non Steril Di Salah Satu Distributor Alat Kesehatan Bandung

\begin{tabular}{cccccc}
\hline No & $\begin{array}{c}\text { Kelompok } \\
\text { Alat } \\
\text { Kesehatan }\end{array}$ & $\begin{array}{c}\text { Jumlah } \\
\text { Item }\end{array}$ & Biaya (Rp) & $\begin{array}{c}\text { Persentase } \\
\text { Item (\%) }\end{array}$ & $\begin{array}{c}\text { Persentase } \\
\text { Biaya } \\
(\%)\end{array}$ \\
\hline 1 & A & 77 & 680.512 .818 & 23,70 & 81 \\
2 & B & 100 & 127.926 .383 & 30,77 & 15 \\
3 & C & 148 & 34.299 .125 & 45,53 & 4 \\
\hline & TOTAL & 325 & 842.738 .326 & 100 & 100 \\
\hline
\end{tabular}




\section{Tabel 4}

Data Analisa ABC Nilai Investasi Alat Kesehatan Non Eletromedik Steril Di Salah Satu Distributor Alat Kesehatan Bandung

\begin{tabular}{cccccc}
\hline No & $\begin{array}{c}\text { Kelompok Alat } \\
\text { Kesehatan }\end{array}$ & $\begin{array}{c}\text { Jumlah } \\
\text { Item }\end{array}$ & Biaya (Rp) & $\begin{array}{r}\text { Persentase } \\
\text { Item (\%) }\end{array}$ & $\begin{array}{c}\text { Persentase } \\
\text { Biaya (\%) }\end{array}$ \\
\hline 1 & A & 45 & 309.177 .082 & 21,17 & 81 \\
2 & B & 56 & 58.567 .428 & 27,59 & 15 \\
3 & C & 102 & 15.740 .728 & 50,25 & 4 \\
\hline & TOTAL & 203 & 383.485 .238 & 100 & 100 \\
\hline
\end{tabular}

\section{B. Pembahasan}

Dari hasil perhitungan metode $\mathrm{ABC}$ nilai pakai dapat dilihat kelompok $\mathrm{C}$ pada penggunaan alat kesehatan non elektromedik non steril adalah $58,16 \%$ dan alat kesehatan non elektromedik steril adalah 63,5\% dari seluruh item alat kesehatan non elektromedik non steril dan steril (Andampury, Dewi, \& Marwati, 2016). Hal ini menunjukkan banyak item alat kesehatan non elektromedik non steril dan steril kelompok $\mathrm{C}$ yang moving-nya sangat rendah. Perhitungan ini dapat digunakan untuk menyeleksi item alat kesehatan non elektromedik non steril dan steril mana saja yang perlu diadakan dan mana yang tidak perlu, karena terlalu banyak item dengan moving rendah akan menyulitkan pemantauan, mempunyai risiko kadaluwarsa serta biaya penyimpanan bertambah besar, Hal yang perlu diperhatikan juga apakah alat kesehatan tersebut dalam kategori vital atau bersifat life saving yang penggunaannya tidak terlalu banyak tetapi tetap harus tersedia walaupun dalam jumlah kecil.

Kelompok B perhitungan persentasenya $27,38 \%$ pada alat kesehatan non elektromedik non steril dan $22,7 \%$ pada alat kesehatan non eletromedik steril. Berdasarkan hasil tersebut menunjukkan bahwa kelompok B adalah item dengan pemakaian sedang, sehingga tidak memerlukan pengawasan yang sangat ketat (Rika, 2010).

Item yang masuk dalam kelompok A merupakan sediaan yang sering digunakan dengan $81 \%$ dari seluruh penjualan alat kesehatan elektromedik steril dan non steril. Dengan demikian perlu dilakukan pengawasan ketat agar tidak terjadi terjadi kekosongan sediaan.

Nilai investasi alat kesehatan pada kelompok A adalah alat kesehatan yang menghabiskan anggaran paling besar, maka perlu dikendalikan secara ketat yaitu dengan membuat laporan penggunaan dan sisanya secara rinci. Pencatatan pada kartu stok juga harus teliti agar dapat dilakukan pengawasan setiap bulan. Oleh karena itu, penyimpanannya juga diperketat untuk menghindari kemungkinan hilangnya persediaan.

Pengendalian alat kesehatan kelompok B tidak seketat kelompok A, tetapi laporan penggunaan dan sisa alat kesehatan dilaporkan secara rinci untuk dilakukan pengawasan secara berkala setiap satu sampai tiga bulan sekali. Stok untuk kedua 
kelompok ini hendaknya ditekan serendah mungkin untuk memudahkan pengendalian, namun persediaannya tetap dapat mencukupi kebutuhan pelayanan alat kesehatan. Pengendalian alat kesehatan kelompok $\mathrm{C}$ yang memakan anggaran paling kecil dalam pengadaan, dapat lebih longgar pencatatan dan pelaporannya dengan dilakukan pengawasan setiap dua sampai enam bulan (Yanti \& Farida, 2016).

\section{Kesimpulan}

Hasil perhitungan nilai pakai alat kesehatan non elektromedik steril dan non steril didapatkan presentase item dan penjualan adalah sebagai berikut:

1. Kelompok A terdiri dari $14,46 \%$ item dan $81 \%$ penjualan untuk alat kesehatan non elektromedik non steril sedangkan untuk alat kesehatan non eletromedik steril terdiri dari $13,8 \%$ item dan $81 \%$ penjualan.

2. Kelompok B terdiri dari $27,38 \%$ item dan $15 \%$ penjualan untuk alat kesehatan non elektromedik non steril sedangkan untuk alat kesehatan non eletromedik steril terdiri dari $22,7 \%$ item dan $15 \%$ penjualan.

3. Kelompok $\mathrm{C}$ terdiri dari $58,16 \%$ item dan $4 \%$ penjualan untuk alat kesehatan non elektromedik non steril sedangkan untuk alat kesehatan non eletromedik steril terdiri dari $63,5 \%$ item dan $4 \%$ penjualan.

Hasil perhitungan nilai investasi alat kesehatan non elektromedik steril dan non steril didapat presentase item dan biaya sebagai berikut:

1. Kelompok A terdiri dari $23,70 \%$ item dan $81 \%$ biaya untuk alat kesehatan non elektromedik non steril sedangkan untuk alat kesehatan non eletromedik steril terdiri dari $21,17 \%$ item dan $81 \%$ biaya.

2. Kelompok B terdiri dari 30,77\% item dan $15 \%$ biaya untuk alat kesehatan non elektromedik non steril sedangkan untuk alat kesehatan non eletromedik steril terdiri dari $27,59 \%$ item dan $15 \%$ biaya.

3. Kelompok $\mathrm{C}$ terdiri dari $45,53 \%$ item dan $4 \%$ biaya untuk alat kesehatan non elektromedik non steril sedangkan untuk alat kesehatan non eletromedik steril terdiri dari $50,25 \%$ item dan $4 \%$ biaya. 
Analisis Pengendalian Alat Kesehatan Non Elektromedik Steril dan Non Steril Menggunakan Metode ABC Di Salah Satu Penyalur Alat Kesehatan Kota Bandung

\section{BIBLIOGRAFI}

Andampury, Fasha Since, Dewi, Arlina, \& Marwati, Triyani. (2016). Analisis Kebijakan Investasi Alat Radiologi C-Arm Rumah Sakit X. Kes Mas: Jurnal Fakultas Kesehatan Masyarakat Universitas Ahmad Daulan, 10(1), 43-54.

Creswell, John W. (2016). Research design: pendekatan metode kualitatif, kuantitatif, dan campuran. Yogyakarta: Pustaka Pelajar, 5.

Farida, Ida, Sunandar, Sunandar, \& Hetika, Hetika. (2017). Analisis Penggunaan Metode Activity Based Costing (ABC) dalam Menentukan Sumbangan Pembinaan Pendidikan (Spp) pada Politeknik Harapan Bersama. Media Riset Akuntansi, Auditing \& Informasi, 17(1), 17-30.

Kemenkes, RI. (2010). permenkes nomor 1191 tahun 2011 Tentang Penyalur Alat Kesehatan. Kementrian Kesehatan Indonesia.

Kemenkes, RI. (2011). permenkes nomor 1148 tahun 2011 Tentang Pedagang Besar Farmasi. Kementrian Kesehatan Indonesia.

Mulyadi. (2016). Activity Based Cost System: Sistem Informasi Biaya untuk Pengurangan Biaya (Edisi 6). Yogyakarta: UPP AMP YKPN.

Perizinan, P. A. K., \& PAK, Cara Mendapatkan Izin. (2011). Perizinan Penyaluran Alat Kesehatan di Republik Indonesia.

Pudjiantoro, Rahardjanto. (2008). Pengembangan Pelayanan Rumah Sakit Umum Daerah Tugurejo-Semarang. program Pascasarjana Universitas Diponegoro.

Pujawati, Helena. (2015). Analisis Sistem Pengadaan Obat dengan Metode ABC Indeks Kritis (Studi Kasus Pengadaan Obat Jaminan Kesehatan Nasional di Rumah Sakit Panti Rapih Yogyakarta). Universitas Sanata Dharma. Yogyakarta.

Reddy, D. V, \& Elanchezhian, N. (2008). Evaluation of tropical tree leaves as ruminant feedstuff based on cell contents, cell wall fractions and polyphenolic compounds. Cellulose (ADF-ADL), 14(21.58), 17-52.

Rika, Pia. (2010). analisis pareto ABC sediaan farmasi puskesmas di kabupaten bantul dengan penyakit utama nasofaringitis akut dan myalgia periode 2009. Skripsi Program Studi Ilmu Farmasi Universitas Sanata Dharma Yogyakarta, 33-36.

Suciati, Susi, Adisasmito, Wiku B. B., \& Wiku, B. (2006). Analisis perencanaan obat berdasarkan ABC indeks kritis di instalasi farmasi. Gadjah Mada University.

Sugiyono, Prof. (2011). Metodologi penelitian kuantitatif kualitatif dan R\&D. Alpabeta, Bandung.

Tampubolon, Kennedi, Saragih, Hoga, Reza, Bobby, Epicentrum, K., \& Asosiasi, A. (2013). Implementasi Data Mining Algoritma Apriori pada sistem persediaan alat- 
Yusuf Supriadi, Nida Yulianti Muchtar dan Akhmad Priyadi

alat kesehatan. Majalah Ilmiah Informasi Dan Teknologi Ilmiah, 1(1), 93-106.

Yanti, Tina Hari, \& Farida, Yeni. (2016). Analisis ABC dalam Perencanaan Obat Antibiotik Di Rumah Sakit Ortopedi Surakarta. JPSCR: Journal of Pharmaceutical Science and Clinical Research, 1(1), 51-57. 